УДК 355.02:327

DOI 10.30970/vir.2018.45.0.9459

\title{
FRANCUSKA POLITYKA BEZPIECZEŃSTWA PO 1989 ROKU
}

\author{
Karolina Użałowicz \\ Uniwersytet Wrocławski, \\ ul. Koszarowa 3, Wrocław, Poland, 51-149, tel. +41 779877899 , \\ e-mail:wojkarolina@interia.pl
}

The article presents the specifics of French security policy and its cooperation within the European Union and The North Atlantic Treaty Organization (NATO). The aim of the article will be to show the democratic character of the French security policy and to show that the undoubted influence on France's security policy is exerted on the one hand by its historical and political tradition, and on the other, by its geopolitical position. The article presents as well a certain inconsistency in French strategy that is associated with evolution of creating its own security policy, and the question: to create it on its own or perhaps with cooperation with the Union? In France, despite the introduction of significant changes after 1989, the very clear accent seems to be continued, which is related to maintaining the strong position of Paris in whole Europe and beyond. France wants to take the leading positions in European organizations, such as the EU or the Council of Europe and actively participates in the meetings of the United Nations Security Council where is insisting of pushing the important strategies for Europe. At the same time, Paris does not agree to US dominance in these institutions believing them to be unnecessary in creating peace in Europe as the Community itself can best take care of its own issues. After taking over the office of the president by Jacques Chirac, the visible desire to strengthen cooperation with the Organization and return to its integrated military structures, implemented only in 2009, can be noticed. France also attaches a great importance to the activities of the United Nation. As a «representative» of Europe in the Security Council, together with Great Britain, it has a right of vote at its meetings. Additionally, in the last years, Paris vote for granting the greater voice in leading institutions for certain European countries and inviting new members to the Security Council. At the same time, France makes a tremendous effort to preserve the traditions of its cultural heritage.

Key words: Security; NATO; France; the European Union; The Council of the EU.

\section{Wstęp}

Centralnym założeniem francuskiej polityki zagranicznej od lat pięćdziesiątych XX wieku było zapewnienie Paryżowi utrzymania nadwyrężonej jednak wciąż upragnionej dominującej pozycji na Starym Kontynencie. W przypadku Francji mamy do czynienia $\mathrm{z}$ niewątpliwie silnym przywiązaniem do tradycji narodowej suwerenności [6, p. 89]. Obecne od wieków przekonanie o możliwości i konieczności odgrywania wyjątkowej roli w świecie nie pozwala Francji na żadne momenty słabości $\mathrm{w}$ prowadzeniu polityki zagranicznej. Owo francuskie exception française jest wciąż pielęgnowane, mimo zmiennych opcji politycznych wśród elit rządzących. Francja, opowiadając się za urzeczywistnieniem wartości globalnych, a zwłaszcza ogólnoeuropejskich, dąży do jednoczesnego zachowania tradycji swego dziedzictwa kulturowego [20, p. 393].

(C) Użałowicz Karolina, 2018 
Państwo francuskie spełnia dzisiaj, w mniejszym lub większym stopniu najważniejsze kryteria mocarstwowości, tj. zdolność kraju do suwerennych działań, zdolność do wymuszania i niedopuszczania do określonych zachowań innych państw oraz zdolność do odmowy podejmowania działań wymuszanych przez inne państwa [4, p. 207]. Ponadto zasadnicze znaczenie dla pozycji Paryża ma też stałe członkostwo w Radzie Bezpieczeństwa, wysoka pozycja gospodarcza i siła militarna, a zwłaszcza potencjał jądrowy. Siły zbrojne Francji liczyły w 2001 roku blisko 300 tysięcy żołnierzy, z czego około 8,5 tysiąca przypadało na jądrowe siły strategiczne [4, p. 208].

Celem artykułu będzie pokazanie demokratycznego charakteru francuskiej polityki bezpieczeństwa oraz ukazanie, że niewątpliwy wpływ na politykę bezpieczeństwa Francji wywierają z jednej strony jej tradycja historyczna i polityczna, z drugiej natomiast, jej położenie geopolityczne. Oba te czynniki wzajemnie się przenikają, czego efektem są mocarstwowe aspiracje Francji do tworzenia dynamicznej polityki bezpieczeństwa. Na obecny kształt francuskiej polityki bezpieczeństwa i obrony zasadniczy wpływ wywierają zarówno pewne elementy tradycyjnej kultury strategicznej, jak i jej modyfikacje wynikające z konieczności dostosowywania ich do wciąż zmieniających się warunków politycznych i społecznych. Zważywszy na fakt, że działania Paryża koncentrują się na trzech najważniejszych z jego punktu widzenia kwestiach: uniwersalizmie, światowej randze i niezależności [4, p. 207], że były one pielęgnowane $\mathrm{w}$ przeszłości, że określają kształt współczesnych relacji i prawdopodobnie wpłyną na przyszłą politykę obronną Francji, narzuca się następujące pytanie: Czy mimo spełnienia wspomnianych warunków «francuska idea wielkości» wciąż pozostaje niekwestionowana? Czy poważne zagrożenia dla Paryża, takie jak pojawiające się trudności w zakresie utrzymania konkurencyjności gospodarki, problemy społeczne, związane ze spadkiem przyrostu demograficznego oraz starzenie się społeczeństwa, jej nie osłabiają?

Francuska polityka bezpieczeństwa - zarys i historia

Francuska polityka bezpieczeństwa i obrony charakteryzuje się precyzją i stałością. Wynika to $\mathrm{z}$ tradycji, ale przede wszystkim z demokratycznego charakteru sprawowania rządów w państwie. Podstawowe zasady i kompetencje organów zarządzających polityką bezpieczeństwa są zawarte w Konstytucji z 4 października 1958 roku. Z kolei wyrazem woli państwa w zakresie wyboru polityki obrony jest «Biała Księga» (2013), którą zatwierdza premier Francji, a potem Rada Obrony. Wszystkie jej wytyczne i zapisane postulaty trafiają do parlamentu i muszą być uwzględnione w budżecie rocznym państwa. Jeżeli chodzi o strukturę kierowania i dowodzenia to jest ona podzielona na trzy poziomy: poziom polityczny, poziom administracji centralnej zarządzany przez ministrów i ich organy pomocnicze oraz poziom dowodzenia wojskami $[4$, p. 214]. Pierwszy poziom wyznacza strategię, a dwa pozostałe zajmuję się jej wykonaniem. Za całokształt polityki obronnej odpowiada prezydent Republiki, który jest zwierzchnikiem sił zbrojnych. To on podejmuje samodzielna decyzję o użyciu sił nuklearnych. Parlament z kolei zatwierdza wszelkie ustawy podejmowane $\mathrm{w}$ tych kwestiach, zwłaszcza jeżeli chodzi o budżet obronny i programy rozwoju sił zbrojnych. Premier odpowiada za ogólne kierowanie operacjami 
militarnymi i kieruje administracją wojskową. Zajmuje się też koordynacją polityki obronnej ze wszystkimi innymi najważniejszymi dziedzinami działalności państwa. Głównym organem konsultatywnym w tych kwestiach jest Sekretariat Generalny ds. Obrony Narodowej (SGDN). Ponadto we Francji występują jeszcze trzy inne ważne organy: Wyższa Rada Obrony Narodowej, która obraduje pod przewodnictwem prezydenta i rozstrzyga ogólne problemy z zakresu obronności państwa, Komitet Obrony obradujący pod przewodnictwem prezydenta, gdzie uczestniczą również premier, minister spraw zagranicznych, minister spraw wewnętrznych, obrony, ekonomii i finansów, a także, w razie potrzeby, również inni ministrowie, Ścisły Komitet Obrony, którym kieruje prezydent, bądź premier i który podejmuje zasadnicze decyzje w kwestiach obrony i bezpieczeństwa [4, p. 215]. Komitet Obrony wraz ze Ścisłym Komitetem Obrony tworzy Radę Obrony. Posiada ona kompetencje z zakresu ogólnego kierowania polityką obronną państwa oraz działaniami militarnymi, a także funkcjonowaniem sił strategicznych. Corocznie sporządzany jest program wspólnych działań w dziedzinie obrony, który formułuje premier. Przed nim, za funkcjonowanie polityki militarnej, odpowiada minister obrony. To właśnie on zajmuje się stroną czysto praktyczną sił zbrojnych - kieruje nimi, odpowiada za ich zdolność bojową, organizację i mobilizację, a także zajmuje się funkcjonowaniem infrastruktury i logistyki wojskowej.

Obecnie Francja w polityce obronnej nadal stosuje «doktrynę odstraszania». Na nowo została ona zapoczątkowana przez Jacques'a Chiraca w 1996 roku w ramach rewolucji strategicznej. Doktryna oparta jest na następujących zasadach: podstawowym celem jest wyeliminowanie wojny, dlatego użycie broni jądrowej jest niewskazane, broń nuklearna może być użyta wyłącznie do obrony żywotnych interesów Paryża, odstraszanie stanowi element strategii i może być użyte jako groźba wobec przeciwnika, broń nuklearna nie jest traktowana jako przedmiot całej walki, tylko początkowy etap, który ma na celu udzielenie ostrzeżenia, decyzję o użyciu broni nuklearnej podejmuje prezydent, Francja nie będzie uczestniczyć w negocjacjach na temat redukcji swojej broni, chyba że inne państwa zredukują swoją broń do poziomu porównywalnego $\mathrm{z}$ ich państwem, Francja nie ma zamiaru grozić bronią nuklearną krajom, które jej nie posiadają [4, p. 218]. W ramach rewolucji strategicznej wprowadzono również model obrony zrównoważonej, który miał zapewnić skuteczną ochronę interesów Francji i być nadrzędnym wobec doktryny odstraszania. Wprowadzał on rewolucję w zakresie polityki obronnej państwa i akcentował wzrost gotowości do podejmowania różnorakich zadań w ramach ochrony najistotniejszych interesów państwa. Nadmieńmy, że Francja aktywnie angażuje się w działania $\mathrm{w}$ zakresie bezpieczeństwa $\mathrm{i}$ autonomii europejskiej $\mathrm{w}$ ramach NATO. Zakłada, że możliwa jest współpraca w ramach Sojuszu bez bezpośredniego nadzoru ze strony Stanów Zjednoczonych. Obecnie obowiązuje teza, że bezpieczeństwo Francji w dużym stopniu zależne jest od systemu obrony, który opierać ma się na mobilności, kolektywności i europejskim charakterze [4, p. 221].

Współczesny uniwersalizm opiera się w dużej mierze na hasłach głoszonych podczas Wielkiej Rewolucji Francuskiej. Większość elit rządzących, czerpie również inspiracje z myśli generała Charles'a de Gaulle’a, który lansował politykę wielkości 
Francji. Sam kraj od dłuższego czasu tworzył wizerunek państwa-obrońcy, któremu bliskie były problemy ubóstwa, biedy oraz losu najsłabszych i pokrzywdzonych. Obecnie znajduje to wyraz w prowadzonych akcjach humanitarnych («Lekarze bez granic»), a także $\mathrm{w}$ angażowaniu się $\mathrm{w}$ akcje pokojowe, gdzie Francja niemal wzorcowo odnajduje się w operacjach służących odbudowie zniszczonych konfliktami i wojnami regionów: budowaniem szkół i przedszkoli, tworzeniem przychodni lekarskich, odnową infrastruktury, dostarczaniem wody i żywności. Istotnym wyrazem wspomnianego uniwersalizmu jest też promowanie na szeroką skalę wartości europejskich i przeciwstawianie się tendencjom globalizacyjnym, zwłaszcza wszechogarniającej amerykanizacji, którą Paryż uznaje za szkodliwą. W kraju tym bardzo często swoboda działania (tzw. liberté d'action) pojmowana jest w kategorii niezależności i wielokrotnie podkreślanej potrzeby «wielkości». Podstawę takiego myślenia stanowi niezależna polityka obrony narodowej. W praktyce idea ta sprzyja utrzymywaniu równowagi pomiędzy strukturami władzy w państwie, a także między władzą a opozycją. Głęboko zakorzenione wartości narodowe powodują, że mimo zmiennych opcji rządzących, idea «wielkości» jest podstawą polityki skoncentrowanej wokół podobnych priorytetów.

$\mathrm{Na}$ francuską politykę bezpieczeństwa i obrony składają się następujące czynniki: «interesy żywotne», które obejmują takie cechy jak integralność terytorialną Francji, suwerenność, podstawowe wartości przynależne każdemu bez względu na wyznanie czy kolor skóry, a także ochronę społeczeństwa przed możliwymi zagrożeniami, «interesy strategiczne», czyli ogólnie pojętą konieczność utrzymania pokoju w Europie, zwłaszcza w rejonie Morza Śródziemnego, Morza Czerwonego i północnej części Oceanu Indyjskiego, terenów szczególnie istotnych dla francuskiej aktywności ekonomicznej i handlowej, «interesy mocarstwowe», a więc międzynarodowa odpowiedzialność Francji wynikającą z jej członkostwa w Radzie Bezpieczeństwa ONZ oraz z posiadanych sił jądrowych [4, p. 211]. Francja uznana została za teren niepodlegający bezpośredniemu zagrożeniu militarnemu. Wynika to przede wszystkim z porozumień i umów międzynarodowych podpisanych i respektowanych przez Pałac Elizejski. W związku $\mathrm{z}$ powyższym państwo angażuje się $\mathrm{W}$ misje służące przeciwdziałaniu konfliktom i reagowaniu kryzysowemu. Ogromne znaczenie ma też działanie na rzecz bezpieczeństwa i stabilizacji międzynarodowej. Zaangażowanie w akcje prowadzone pod auspicjami NATO jest jednym z kluczowych elementów francuskiej polityki zagranicznej, a udział w misjach Sojuszu ma priorytetowy charakter, gdyż stanowi przede wszystkim istotny wyznacznik miejsca i roli tego kraju na arenie międzynarodowej, potwierdzając jednocześnie wiarygodność Francji jako członka NATO. Dąży tym samym do stworzenia systemu wspólnej obrony europejskiej w postaci wojskowego «ramienia» Unii. Miałoby ono stanowić alternatywę wobec polityki Stanów Zjednoczonych i stworzyć europejski filar Sojuszu Północnoatlantyckiego.

Aktualnie francuska polityka obronna wyznacza sobie trzy główne cele. Pierwszym z nich jest ochrona terytorium narodowego i stref mu przyległych, a także zabezpieczenie interesów tych państw przed wszelkimi zagrożeniami. Koniecznością jest stworzenie gwarancji odpowiednio rozbudowanego czynnika militarnego, gdyż w 
przypadku jego braku trwałość interesów europejskich byłaby zagrożona. Drugim celem francuskiej polityki bezpieczeństwa i obrony jest stworzenie tzw. stabilizacji międzynarodowej, ze szczególnym naciskiem na przyszły kierunek ewolucji współpracy europejskiej. Konieczność nawiązania bliższego partnerstwa z NATO, z jednoczesną potrzebą utrzymania europejskiej tożsamości w zakresie obrony, stała się ważnym punktem działań, gdyż z zasady wnosi duży wkład w proces utrzymania pokoju w ramach ONZ i OBWE. Ostatnim, trzecim celem Francji jest chęć rozbudowania własnego systemu obrony $\mathrm{w}$ takim zakresie, by nie ograniczał się tylko do aspektów militarnych. Paryż chce, aby obejmował on jak największy obszar jego aktywności i dzięki temu stał się jego naturalną częścią [4, p. 213].

W 1976 roku powstała we Francji doktryna tzw. trzech sfer lub też trzech kręgów. Wyznaczały one francuskie interesy na arenie międzynarodowej, do których zaliczono również politykę bezpieczeństwa. Pierwszy krąg tworzyło terytorium narodowe, drugi krąg cała Europa, a trzeci reszta świata. Po drugiej wojnie światowej strefy te nabrały szczególnego znaczenia. W czasie prezydentury de Gaulla priorytety polityki koncentrowały się wokół pierwszej wersji, a więc interesu narodowego. Jego następca - Georges Pompidou - również skupiał swoje działania wokół pierwszej strefy, jednak w niektórych jego posunięciach zauważyć też można elementy charakterystyczne dla kręgu drugiego. Wtedy to zaczęła obowiązywać «doktryna Fourquet'a», która dopuściła możliwość działania poza terytorium Francji. W dobie prezydentury Valéry'ego Giscarda d'Estaing zauważamy wprowadzenie do polityki bezpieczeństwa elementów z kręgu trzeciego. Wielu specjalistów twierdzi, że pomysł ten nie był inicjatywą samej głowy państwa, ale był wymuszony koniecznością zareagowania na kryzysy w Mauretanii, Czadzie, Zairze i Libanie. Dopiero prezydentura François Mitteranda spowodowała świadome wprowadzenie równowagi w zakresie polityki obronnej. Modernizowano siły jądrowe, stworzono oddziały szybkiego reagowania oraz nie dopuszczono do rozmieszczenia na terytorium Francji rakiet amerykańskich. Po przejęciu rządów przez Jacques'a Chiraca rozpoczęto budowę autonomicznej obrony europejskiej, która miała doprowadzić do stworzenia nowego partnerstwa między Europą i Stanami Zjednoczonymi. Działanie to miało zwiększyć rolę Europy i Francji, a ściślej Unii Europejskiej w stabilizowaniu konfliktów na świecie.

\section{Współpraca w ramach Unii Europejskiej i NATO}

W tym momencie warto zwrócić uwagę na ewolucję francuskiej polityki bezpieczeństwa, a mianowicie dość burzliwą współpracę nie tylko w ramach Unii Europejskiej, ale również i NATO. Bezpieczeństwo Europy Zachodniej po II wojnie światowej było nierozerwalnie związane $\mathrm{z}$ Sojuszem Północnoatlantyckim, powołanym Traktatem Północnoatlantyckim z 4 kwietnia 1949 r. w Waszyngtonie [9, pos. 970]. To właśnie $\mathrm{w}$ ramach tej organizacji podejmowano decyzje dotyczące bezpieczeństwa na całym świecie. Istotne zmiany w stosunkach międzynarodowych przyniosły lata dziewięćdziesiąte XX wieku. Pojawiła się nowa wizja bezpieczeństwa europejskiego, spotęgowana zwłaszcza rozpadem Związku Radzieckiego, a tym samym wyeliminowaniem groźby zmasowanego ataku na wschodnich i zachodnich europejskich frontach NATO. W Traktacie o Unii Europejskiej, podpisanym w Maastricht 7 lutego 1992 roku, stwierdzono, że: «Wspólna polityka zagraniczna i 
bezpieczeństwa obejmuje wszystkie te kwestie, które są związane z bezpieczeństwem Unii Europejskiej łącznie z docelowym określeniem wspólnej polityki obronnej, która mogłaby z czasem prowadzić do wspólnej obrony». Instytucją odpowiedzialną za realizację tej wizji była Unia Zachodnioeuropejska, nazwana «integralną częścią rozwoju Unii Europejskiej» [13, p. 124]. Zdefiniowała ona podstawowe cele nowej polityki zagranicznej: ochrona wspólnych wartości, podstawowych interesów i niezależności państw członkowskich, umacnianie bezpieczeństwa Unii Europejskiej i poszczególnych jej członków, umacnianie bezpieczeństwa kontynentu i wspieranie współpracy międzynarodowej, ugruntowanie i rozwijanie demokracji i rządów prawa oraz poszanowania praw człowieka i podstawowych wolności obywatelskich. Niestety w praktyce Traktat okazał się niekompletny, zabrakło w nim informacji o organach dowodzenia i instrumentach nowej polityki.

Kolejne zmiany przyniósł Traktat Amsterdamski (1997), który uzupełnił działania Europy o misje petersberskie: zadania humanitarne, misje ratownicze, pokojowe i zarządzanie sytuacjami kryzysowymi. Konieczność podjęcia współpracy w ramach całej Unii stała się szczególnie widoczna podczas wojny w Zatoce Perskiej w 1991 roku. Wtedy to Stany Zjednoczone wysłały w rejon konfliktu około 450 tysięcy żołnierzy, a cała Europa zaledwie kilkadziesiąt tysięcy. Istotny w tej mierze był również brak jakiegokolwiek zaangażowania ze strony Niemiec. Podjęto więc decyzję, że główną rolę w europejskiej polityce bezpieczeństwa przejmie właśnie Unia Zachodnioeuropejska. Stany Zjednoczone wyraźnie zaapelowały, że jeżeli Europa będzie chciała w jakikolwiek sposób zmniejszyć rolę NATO przy pomocy UZE, to Amerykanie wycofają się ze Starego Kontynentu. Mitterrand przekonywał administrację USA o słabości europejskiej polityki bezpieczeństwa i jej konieczności rozpatrywania wyłącznie w ramach Sojuszu jeszcze przez bardzo długi okres. Stany jednak wciąż pozostawały nieufne.

Kluczowym elementem okazał się szczyt w Rzymie. Rada Północnoatlantycka uznała, że «europejska tożsamość w sferze bezpieczeństwa i obrony, znajdująca swe odzwierciedlenie we wzmocnieniu europejskiego filaru w łonie Sojuszu, będzie służyć nie tylko interesom państw europejskich, ale całemu Sojuszowi» [22, p. 290]. Francja od początku była świadoma, że od wzmocnienia Unii Zachodnioeuropejskiej zależeć będzie przyszły kształt Wspólnej Polityki Zagranicznej i Bezpieczeństwa. Z jej inicjatywy powstały więc w czerwcu 1992 roku Siły Podległe UZE (FAWEU), w skład których miały wchodzić narodowe i wielonarodowe oddziały. Jednostki te, w imię wspólnego dobra, miały zostać udostępnione Unii przez państwa członkowskie, aby ta mogła skutecznie wykonywać swoje działania. Paryż w ramach prac Korpusu Europejskiego, a z czasem również EUROFORU i EUROMARFORU aktywnie wspierał działalność Unii, angażując ją nie tylko w misje wynikające z Traktatu Waszyngtońskiego, ale też misje petersberskie, dążył też do nawiązania współpracy z krajami Europy Środkowej. Utworzono więc Forum Konsultacyjne na szczeblu Stałej Rady UZE i ambasadorów państw tej części Europy, a w 1994 roku, z inicjatywy Francji i Niemiec, przyznano krajom Europy Środkowej status partnerów stowarzyszonych. Dzięki temu państwa te miały możliwość uczestnictwa w pracach Rady Ministrów UZE z głosem doradczym, a także mogły brać udział w misjach 
humanitarnych, ratowniczych, operacjach pokojowych i zarządzania kryzysami [24, p. 74].

Obie te inicjatywy miały na celu ograniczenie wpływów NATO w Europie. Wbrew aspiracjom Francji, Unia Zachodnioeuropejska nie stała się fundamentem europejskiej strategii obrony. Pomysł ten tak naprawdę nigdy nie zyskał akceptacji większości państw europejskich ani Stanów Zjednoczonych. Walka Paryża o zmarginalizowane roli NATO na Starym Kontynencie spowodowała tylko jego dalszą izolację. Z tego też powodu, Francja podjęła próbę tworzenia wspólnej polityki bezpieczeństwa na bazie zreformowanej Organizacji Traktatu Północnoatlantyckiego [22, p. 291]. Pomysł trafił do opinii publicznej po licznych przemowach Jacques'a Chiraca, który wyrażał przekonanie o konieczności aktywniejszego uczestnictwa jego kraju w pracach Sojuszu, tak by stał się on sojuszem dwóch równoprawnych partnerów - Ameryki i Europy Zachodniej. Na szczycie w Brukseli w 1994 roku podjęto próbę znalezienie «złotego środka» we wzajemnych kontaktach Europa-USA. Powstały Połączone Siły do Zadań Specjalnych (CJTF), które «rozdzielnie, lecz nie odrębnie» od NATO, współpracowały i dążyły do stworzenia «Europy obrony» [22, p. 292]. W konsekwencji, Europa zrozumiała, że bez pomocy Stanów jej państwa nie będą w stanie skutecznie stawić czoła nowym wyzwaniom. Z kolei NATO coraz mniej angażowało się w działania europejskiej polityki bezpieczeństwa, dzięki czemu państwa te mogły zadbać o większą niezależność w tworzeniu własnej wizji obrony.

Drugą osią wielostronnej współpracy Francji w kwestii obrony i bezpieczeństwa była wspomniana już Unia Europejska. W latach 1996-1997 Chirac i Kohl ogłosili plan zakładający stopniową integrację UZE i UE, a rok później ci sami przywódcy opowiedzieli się za wyposażeniem Wspólnoty w zdolności operacyjne. Miało tak się stać bądź za pośrednictwem UZE, bądź dzięki Sojuszowi [6, p. 1-3]. We francuskobrytyjskiej deklaracji na temat obrony europejskiej, podpisanej w grudniu 1998 roku w Saint Malo, głowy rządów obu państw podkreśliły konieczność zaangażowania całej Unii Europejskiej w tworzenie wspólnej polityki bezpieczeństwa i obrony. Zaznaczono, że Wspólnota powinna posiadać odpowiednie struktury i zdolność podejmowania samodzielnych akcji, aby unikać dublowania jej działalności z misjami i zadaniami NATO [12, p. 1-3]. Kraje unijne, wzmocnione solidarnością innych państw członkowskich, posiadały możliwość stworzenie silnego głosu Europy w kwestiach bezpieczeństwa. Szczyt w Saint Malo w przekonaniu wielu analityków był efektem otwarcia się Wielkiej Brytanii na szeroką współpracę w ramach Unii. Niektórzy twierdzili też, że Anglia chciała tym samym zrekompensować się Europie za swoją rezygnację z innego kluczowego projektu, jakim była unia monetarna. Abstrahując jednak od brytyjskich czy francuskich przesłanek, trzeba przyznać, że wspólna inicjatywa, w połączeniu $\mathrm{z}$ ich politycznym i militarnym znaczeniem na kontynencie, stworzyła niezaprzeczalny argument możliwości poprowadzenia europejskiej polityki bezpieczeństwa i obrony. W konsekwencji państwa UE przystąpiły do budowania, w ramach WPZiB - Wspólnej Europejskiej Polityki Bezpieczeństwa i Obrony CESDP (Common European Security and Defence Policy). Szczegółowe postanowienia przyjęto podczas posiedzeń Rady Europejskiej w Kolonii 
(3-4 czerwca 1999 r.), Helsinkach (10-11 grudnia 1999 r.) i Nicei (7-9 grudnia 2000 r.) [14, p. 1-3].

Paryż, aby w jak najlepszy sposób służyć rozwojowi europejskiej polityki obrony, podjął się również współpracy dwustronnej w granicach kontynentu. Przywiązywał ogromne znaczenie do współpracy wojskowej z Niemcami, Wielką Brytanią, a także Europą Południową. Główny nacisk kładł na kontakty z Berlinem. Tylko te dwa państwa były w stanie realnie przeciwstawić się dominacji amerykańskiej. Nawiązanie dwustronnej współpracy na tym szczeblu przewidywał już Traktat Elizejski, a dwadzieścia pięć lat później, Mitterrand i Kohl utworzyli Francusko-Niemiecką Radę Bezpieczeństwa i Obrony. Po zjednoczeniu Niemiec nastąpiło ochłodzenie wzajemnych zapałów. Jednak już w roku 1992, na szczycie w La Rochelle podjęto decyzję o utworzeniu Korpusu Europejskiego. Była to wielonarodowa jednostka zrzeszająca wszystkie państwa członkowskie UZE, której celem było wzmocnienie współpracy z Sojuszem Północnoatlantyckim, z jednoczesną chęcią wyposażenia Unii we własne zdolności wojskowe [8, p. 249-250]. Korpus stał się w pełni operacyjny jesienią 1995 roku. Trzy lata później jego sztab przejął dowództwo nad Siłami Stabilizacyjnymi NATO (SFOR) w Bośni, a od 2000 roku dowodził siłami KFOR w Kosowie [22, p. 28]. Kolejnym ważnym wydarzenie w dwustronnych stosunkach Francji z innymi państwami było opracowanie w 1996 roku w Norymberdze «wspólnej koncepcji francusko-niemieckiej w dziedzinie bezpieczeństwa i obrony» [22, p. 292]. Jej cele skupiały się wokół czterech zasadniczych elementów: wspólne wyznaczenie celów polityki bezpieczeństwa i obrony, wspólna analiza środowiska bezpieczeństwa, wspólne podejście do strategii i zadań sił zbrojnych oraz wspólne wytyczne w kwestii współpracy wojskowej i współpracy w sferze przemysłu zbrojeniowego. Oba państwa opowiedziały się za koncepcją aktywnej współpracy w ramach Unii pod egidą Rady Europejskiej. Jednocześnie koncepcja była uwiecznieniem francusko-niemieckiej współpracy w sferze bezpieczeństwa, choć, co warto podkreślić, nie rozwiązała wszystkich problemów trapiących oba te kraje.

Drugim ważnym partnerem Francji w kwestii wspólnego zacieśniania współpracy była Wielka Brytania. Jedną z ważniejszych inicjatyw było porozumienie pomiędzy francuskimi Siłami Szybkiego Reagowania i brytyjską armią lądową z 1994 roku, a także decyzja z tego samego roku o utworzeniu Francusko-Brytyjskiej Europejskiej Grupy Powietrznej. Oba kraje angażowały się w misje pokojowe, humanitarne i misje stabilizacyjne. W XXI wieku rządy Paryża i Londynu kładły nacisk na wzajemne kontakty między siłami powietrzno-morskimi oraz na wspólną produkcję lotniskowców. Europejska Polityka Bezpieczeństwa i Obrony w programie prezydencji francuskiej na rok 2008 była jednym z jej najważniejszych zadań. Prezydent Nicolas Sarkozy i minister spraw zagranicznych Bernard Kouchner zapowiedzieli podjęcie inicjatyw mających na celu uporanie się ze słabościami EPBiO. Przede wszystkim, Francja zaproponowała rozbudowę zdolności wojskowych Unii Europejskiej, tak by było możliwe prowadzenie kilkunastu akcji ekspedycyjnych jednocześnie. Kluczowym było tutaj zastosowanie potrzebnych manewrów, takich jak strategiczny i operacyjny transport lotniczy i morski, tankowanie w locie czy rozbudowa rozpoznawczych systemów satelitarnych. Kolejnym projektem było 
usprawnienie zarządzania misjami EPBiO poprzez wprowadzenie formuły umożliwiającej ministrom obrony państw członkowskich zasiadanie w Radzie ds. Ogólnych i Stosunków Zewnętrznych. Prezydencja zamierzała zaktualizować Europejską Strategię Bezpieczeństwa, co wyrażało się w nowej ocenie zagrożeń w Unii oraz poszerzeniu uzgodnień dotyczących kształtu partnerstwa z NATO. Francja wyraziła ogromną chęć wzmocnienia współpracy z Sojuszem, m.in. poprzez wypracowanie trwałych mechanizmów komunikacji i koordynacji działań, zwłaszcza w sytuacjach prowadzenia równoległych operacji. Rząd francuski zapowiedział też możliwość wprowadzenia tzw. solidarności finansowej i możliwie równomiernego podziału kosztów, tak aby państwa wystawiające największe kontyngenty nie ponosiły jednocześnie największych opłat. Niestety, nie przedstawiono żadnej oficjalnej propozycji rozwiązania problemu, dlatego też kwestia «wspólnych» wydatków pozostała wciąż nierozwiązana [23, p. 1-2].

W okresie «zimnej wojny» aż do lat dziewięćdziesiątych, Francja nie przywiązywała pierwszoplanowego znaczenia do europejskiej współpracy w dziedzinie polityki obronnej. Przywódcy francuscy zyskali wówczas świadomość, że im bardziej pozwolą Sojuszowi ingerować w sprawy swojego kontynentu, tym większą rolę będzie on odgrywał w decyzjach europejskich. Jednocześnie nie chcieli doprowadzić do sytuacji, w której Waszyngton definitywnie wycofałby się z Europy. Po 2000 roku znów zapanowało w Paryżu przekonanie, iż to potęga militarna Unii stanowi kluczowy element Europy-mocarstwa. W związku z tym niepotrzebna już jej dominująca rola Stanów Zjednoczonych, tak jak to miało miejsce w latach pięćdziesiątych, gdy Europejska Wspólnota Obronna była de facto podporządkowana Ameryce [22, p. 279]. Po stworzeniu w Europie wspólnych instytucji politycznych, państwa Starego Kontynentu mogły samodzielnie podjąć współpracę w sferze bezpieczeństwa $[15$, p. 1-3]. Według francuskich polityków działających $\mathrm{w}$ tamtym okresie, interesy Europy były odmienne od interesów naszego zaatlantyckiego sąsiada, dlatego tak ważne wydawało się wypracowanie osobnej polityki obronnej. Unia Europejska podjęła się więc w 2003 roku pierwszych samodzielnych misji pokojowych: w Bośni i Hercegowinie, Macedonii czy afrykańskiej Ituri. Z drugiej strony, jak pokazało doświadczenie, sama Wspólnota nie jest w stanie zapobiec wszystkim konfliktom, m.in. tym na Bałkanach. Poruszona w 2003 roku w projekcie traktatu konstytucyjnego «klauzula solidarności» między USA i Europą powinna być pielęgnowana, tym bardziej, iż współczesne wyzwania, takie jak terroryzm, niestabilność i konflikty, zmuszają kraje całej planety do współpracy i międzynarodowej interwencji, a także do wypracowania równowagi pomiędzy pełną suwerennością przy jednoczesnym pogłębianiu współpracy z najbliższymi partnerami [10, p. 5-10].

Francja była jednym z państw, które 4 kwietnia 1949 roku podpisały traktat powołujący do życia Sojusz Północnoatlantycki. Zaraz potem zaangażowała się w budowanie zintegrowanej struktury wojskowej NATO, aby w 1966 roku z niej wystąpić. Wyprowadzenie Francji przez prezydenta Charles'a de Gaulle'a ze zintegrowanych struktur militarnych stało się wyrazem tzw. exception française, owej francuskiej wyjątkowości w polityce zagranicznej. Stabilność rządów, stałe 
członkostwo w Radzie Bezpieczeństwa ONZ, posiadanie broni atomowej oraz dobra pozycja w światowej gospodarce dawały de Gaulle'owi możliwość odegrania istotnej roli na arenie międzynarodowej. W 1958 roku zaproponował utworzenie tzw. dyrektoriatu trzech państw, w skład którego miały wchodzić Stany Zjednoczone, Francja i Wielka Brytania. Prezydent postulował konieczność podejmowania decyzji dotyczących bezpieczeństwa światowego przez te trzy państwa, ale na takich samych zasadach, czyli bez jakiejkolwiek dominacji któregokolwiek z nich. Propozycja spotkała się z odmową ze strony amerykańskiego partnera, z kolei Francja nie chciała zrezygnować $\mathrm{z}$ mocarstwowych aspiracji. W związku z tym była gotowa samodzielnie zmodyfikować warunki swojego uczestnictwa w NATO, sprzeciwiając się tym samym dominacji USA w tworzeniu ładu światowego. Występując ze struktur, kraj ten de facto nie przestał być członkiem całego Sojuszu. Wręcz przeciwnie, wciąż znajdował się w czołówce europejskich sojuszników, a jego wydatki na obronę wynosiły około $2 \%$ PKB wpłacanego każdego roku [18, p. 1-4].

Zasadniczo proces wycofywania wojsk francuskich spod dowództwa składał się z trzech etapów: wyprowadzenie floty śródziemnomorskiej na Morzu Śródziemnym w 1959 roku, odmowa uczestnictwa w zintegrowanym systemie obrony powietrznej NATINAD oraz wycofanie od 1964 roku spod sojuszniczego dowództwa francuskiej eskadry Atlantyku. W konsekwencji nastąpiło wycofanie się wojsk amerykańskich i demontaż ich wszelkich baz i instalacji na terytorium Francji. Ogromnym i kłopotliwym zarazem przedsięwzięciem było przeniesienie kwatery dowodzenia militarnego sił NATO w Europie SHAPE z Rocquencourt do belgijskiego miasta Mons, a nowa siedziba Sojuszu przeniosła się z Paryża do Brukseli. Ze względu na swoje wysiłki zmierzające do wyrównania wpływów w ramach organizacji, Francja, w przeciwieństwie np. do Wielkiej Brytanii, była postrzegana jako tzw. enfant terrible Sojuszu.

Od roku 1990 politykę Paryża wobec NATO można podzielić na trzy fazy. Pierwszy etap to polityka dystansowania się za prezydentury François Mitteranda. Sojusz zyskał status platformy zrzeszającej europejskie państwa demokratyczne, gdzie decyzje podejmowano poza Francją - na gremiach wojskowych. V Republika pozostawała więc nie do końca doinformowana w sprawach istotnych, toczących się $\mathrm{w}$ ramach organizacji. Po wyborach prezydenckich, wygranych przez Jacques Chiraca, rozpoczęto starania o stopniowy powrót do NATO i możliwość pełniejszego partnerstwa $\mathrm{w}$ organizacji. Po raz kolejny celem negocjacji była chęć wzmocnienia pozycji Europy w ramach Sojuszu, która miała wyrażać się w przejęciu przez Francuzów Dowództwa Południowego Nepalu. Miejsce to miało dla Paryża znaczenie doktrynalne i strategiczne, pozwoliłoby bowiem przejąć kontrolę nad Morzem Śródziemnym, o którym w liście do Billa Clintona pisał Jacques Chirac: «[...] wydaje mi się usprawiedliwione, że dwa dowództwa regionalne będą przyznane Europejczykom. Należy zdawać sobie sprawę $\mathrm{z}$ tego, że Europejczycy muszą przywiązać wagę do ewolucji świata śródziemnomorskiego, który jest im tak bliski. Pod względem demograficznym, ekonomicznym, politycznym i strategicznym region śródziemnomorski jest dla Europy istotnym wyzwaniem. Jest nieodzowne, dla Europy i dla Sojuszu, aby Europejczycy wzięli na siebie odpowiedzialność w tym regionie, 
rzecz jasna $\mathrm{W}$ ścisłej współpracy ze Stanami Zjednoczonymi» [5, p. 20]. W odpowiedzi Waszyngton nie przystał na żądania Francji, uznając flotę śródziemnomorską za zbyt istotną dla własnej polityki mocarstwowej. W zamian za to ministrowie spraw zagranicznych państw NATO na posiedzeniu w Berlinie zdecydowali, że udostępnią swoje zasoby militarne dla operacji prowadzonych pod zwierzchnictwem Unii Zachodnioeuropejskiej. Europejczycy zyskali tym samym samodzielność w prowadzeniu niektórych działań, co zostało optymistycznie przyjęte nad Sekwaną. Szybko jednak oznaki zadowolenia zostały zastąpione przez uczucie porażki. Prezydent musiał zrezygnować ze starań o powrót do NATO, gdyż korzyści Francji we wspólnych konsultacjach okazały się dlań niewystarczające. Nie zrezygnowano bynajmniej z przyznanych w 1995 roku miejsc w Komitecie Wojskowym i uczestnictwa w zebraniach ministrów obrony państw Sojuszu [18, p. 14]. Postulaty w ramach EPBiO, zapowiedziane przez nowo zaprzysiężoną głowę Republiki Francuskiej, Nicolasa Sarkozego, nie zmieniły się mimo upływu lat. Prezydent za misję wyznaczył sobie potrzebę «znormalizowania» wzajemnych stosunków z NATO [3, p. 7]. Opowiadał się za nowym podziałem odpowiedzialności w ramach organizacji, za zwiększeniem udziału europejskich oficerów i generałów w strukturach dowodzenia. W czasie swojej kampanii nie wspominał o chęci powrotu do struktur militarnych NATO. Jednakże w opracowanej na jego żądanie w 2008 roku tzw. Białej Księdze Obrony i Bezpieczeństwa Narodowego, wymienił warunki pełnego uczestnictwa: swoboda oceny przez władze francuskie - Paryż chce zachować możliwość podejmowania suwerennie decyzji dot. wysłania swoich wojsk na operacje militarne Sojuszu, niezależność nuklearna Francji, swoboda decyzji dot. zaangażowania sił francuskich - żadne siły francuskie nie mogą na stałe podlegać dowództwu NATO w czasie pokoju [2, p. 93-99].

Prezydent Sarkozy w jednym z wrześniowych wywiadów dla «New York Timesa» z 2007 roku ujawnił warunki ponownego włączenia Francji do struktur wojskowych NATO [16, p. 1]. Pierwszym był «postęp, jeżeli chodzi o europejską politykę obronną». Chodziło tutaj o wyposażenie Unii we własną, niezależną armię, która mogłaby być użyta do interwencji pokojowych bez ubiegania się o zgodę Sojuszu. Drugim warunkiem było miejsce dla przedstawiciela Francji na najwyższych natowskich szczeblach dowodzenia. Sarkozy wiedział, że o ile drugi warunek jest możliwy do spełnienia, o tyle własna armia powinna spotkać się z amerykańskim oporem. Już teraz obie strony rywalizują i nie potrafią się porozumieć w kwestiach przydziału sprzętu czy żołnierzy. «Mamy problem z jednoczesnym zapewnieniem żołnierzy misjom NATO, UE i ONZ», przyznał rzecznik Sojuszu James Appathurai. Warto jednak zauważyć, że polityka Sarkozego znacznie wybiegała poza standardy jego poprzedników, co również rzutowało na decyzję o powrocie do NATO. Były szef MSW był na pewno mniej antyamerykański niż Chirac czy Mitterrand. Miał też większą świadomość tego, że bezpieczeństwo jest problemem globalnym i że trzeba współpracować z dużymi graczami, a w szczególności Stanami, aby je utrzymać [19, p. 1].

Po 2001 roku na pierwszy plan zaczęła wysuwać się problematyka walki z terroryzmem. Głoszona chęć powrotu Sarkozego do pełnego członkostwa w Sojuszu 
nie spotkała się z przychylną reakcją opinii publicznej, wciąż bardzo antybushowskiej. Ostatecznie, 19 marca 2009 roku prezydent Sarkozy w liście do sekretarza generalnego Jaapa de Hoop Scheffera, zwrócił się oficjalnie z prośbą o włączenie Francji we wszystkie struktury NATO. Premier François Fillon poddał kwestię powrotu do Sojuszu pod ocenę parlamentu, wnosząc jednocześnie o wotum zaufania dla swego gabinetu. Francuskie Zgromadzenie Narodowe poparło wniosek. Za decyzją rządu głosowała większość deputowanych. Jak podkreślił premier, powrót kraju do struktur nie jest radykalną zmianą, a jedynie «przystosowaniem»: «Francja sojusznik, lecz nie wasal, wierna, lecz niezależna, zawsze przyjacielska, lecz nigdy niepodporządkowana: oto charakter naszych stosunków z Amerykąı [17, p. 1].

Sytuacja ta wywołała fale pytań i dyskusji: czy powrót Francji spowoduje zahamowanie, czy też może wzmocnienie europejskiej polityki obronnej? Zwolennicy argumentowali, że odsunięcie Paryża od podejmowania istotnych decyzji, w sytuacji, gdy zajmuje on piąte miejsce pod względem ilości wysyłanych do Afganistanu żołnierzy, byłoby niewłaściwe [1, p. 11]. Jak zauważył podczas jednych ze swoich wystąpień prezydent Sarkozy, NATO było jedyną organizacją międzynarodową, w której Francja nie chciała przejąć decydującej i wpływowej roli. Wolała się od niej zdystansować w celu stworzenia własnej strategii rozwoju i niezależności politycznej [7, p. 1-2]. Tym samym powrót $w$ imię uniwersalnej odpowiedzialności za losy świata okazał się konieczny. Była przeciwniczka Sarkozego w walce o fotel prezydencki, Ségolène Royal, zarzucała swojemu przeciwnikowi, że reintegracja z Sojuszem może oznaczać koniec niezależnej polityki Francji. Dotychczas bazowała ona na dialogu politycznym i mediacji, a po wstąpieniu do struktur Paryż nie będzie miał możliwości sprawowania roli mediatora w konfliktach międzynarodowych. Jak stwierdziła była minister, Francja będzie od tej pory «naznaczona» przynależnością do jednego $\mathrm{z}$ obozów politycznych [21, p. 7]. W odpowiedzi prezydent wyraźnie zaznaczył, że Francja wciąż będzie w pełni niezależna, jeżeli będzie chodzić o decyzje podejmowane $\mathrm{w}$ ramach NATO $\mathrm{i}$ nie zrezygnuje $\mathrm{z}$ roli mediatora pomiędzy Wschodem i Zachodem, czego wyraźnym potwierdzeniem była znacząca rola Pałacu Elizejskiego w sporze między Syrią a Libanem.

Wnioski. We Francji, mimo wprowadzenia po 1989 roku istotnych zmian i pojawienia się wielu nowych akcentów, bardzo wyraźny wydaje się element kontynuacji zapoczątkowanej już wcześniej polityki zagranicznej, dążącej do odzyskania mocarstwowej pozycji Paryża w Europie, a także i poza nią. Europa jest uznawana za organizm, który może wzmocnić narodowy potencjał Paryża. Symbolem tego jest slogan «silnej Francji w silnej Europie». Już sam powrót do NATO można thumaczyć chęcią wzmocnienia prestiżu Francji na arenie międzynarodowej, a więc podążania za upragnioną polityka wielkości. Sami Europejczycy nie mogą mieć nadziei na odgrywanie istotnej roli $\mathrm{w}$ łonie NATO, jeśli jedno $\mathrm{z}$ ich największych mocarstw pozostałoby na zewnątrz Sojuszu. A Paryż pod względem militarnym jest jednym z ważniejszych członków Sojuszu Północnoatlantyckiego. Jednak relacje dwustronne między tymi partnerami, mimo wspólnych wartości i interesów, wciąż są skomplikowane, a Francja na nowo zaczyna być postrzegana jako współczesne enfant terrible Sojuszu. Po kryzysie irackim, zarówno Paryż, jak i Waszyngton, przekonały 
się o swoich przywódczych ograniczeniach. Stanom Zjednoczonym potrzebny jest «wspólnik», który wspomógłby niezwykle kosztowne operacje w Iraku i na Bliskim Wschodzie. Francja zaś ma szansę wpłynąć na kształt amerykańskiego przywództwa i stać się w nim równorzędnym partnerem.

\section{BIBLIOGRAFIA}

1. Alançon F., La France prépare son retour dans l'OTAN, «La Croix» 6 II 2009.

2. Barthelen Ch., Istota Białej Księgi Bezpieczeństwa i Obronności, «Zeszyty Naukowe AON» 2008, nr 1.

3. Cholewa M., Relacje Francji z NATO. Powrót do zintegrowanych struktur militarnych, «Biuletyn OPINIE» 2009, nr 17.

4. Ciupiński A., Malak K., Bezpieczeństwo polityczne i wojskowe, Warszawa 2004.

5. Cogan Ch., Diplomatie à la française, Jacob-Duvernet, Paris 2008.

6. Deklaracja końcowa szczytu francusko-niemieckiego, Poczdam [1 XII 1998], www.diplomatie.fr (30.12.2017).

7. Discours de Monsieur le Président de la République. Clôture du Colloque sur La France, La Défense Européenne et L'OTAN au XXIème Siècle (11 mars 2009), www.elysee.fr, (30. 12.2017).

8. Duke S., The Elusive quest for European Security: From EDC to CFSP, New York 2000.

9. Dz. U. 2000, nr 125, poz. 970: Traktat Północnoatlantycki sporządzony w Waszyngtonie, 4 IV 1949.

10. Hoffman T., Francuska polityka bezpieczeństwa i obrony, «Wroclawskie Studia Politologiczne», nr 19/2015.

11. Jaworski K., Ewolucja tradycyjnych wyznaczników polityki zagranicznej Francji w okresie V Republiki, «Myśl Ekonomiczna i Polityczna» 2011.

12. Joint Declaration issued at british-french summit, Saint-Malo, France [3-4 XII 1999], https://www.consilium.europa.eu (30.12.2017).

13. Kowalski J., Ślusarczyk Z., Unia Europejska. Proces integracji europejskiej i zarys problematyki instytucjonalno-prawnej, Poznań, 2006.

14. Kuźniar R., Wzlot $i$ upadek Europejskiej Polityki Bezpieczeństwa $i$ Obrony, https: //www.bbn.gov.pl, (29.12.2017).

15. Mitterand F., Przemówienie na forum Instytutu Wyższych Studiów nad Obrona Narodowa (IHEDN) (Paryż, 11.10.1988 r.), «Le Figaro» 2002, 25 II.

16. Niklewicz K., Za co Francja wróci do NATO?, http://wyborcza.pl/1,75399,4517194.html, (25.09.2017).

17. Pietraszek P., Francja wraca do struktur wojskowych NATO, http://www.bankier.pl, (09.02.2017).

18. Posel-Częścik E., Sojusz Pótnocnoatlantycki w polityce zagranicznej Francji, «Biuletyn PISM» 2004, nr 15.

19. Pszczółkowska D., Francja cała w NATO, http://wyborcza.pl/1,75399,5086278.html, (05.04.2017).

20. Roche J.-J., La France et l'Universel, «Annuaire francais des relations internationals» 2000, nr 1.

21. Royal S., Nicolas Sarkozy commet un contresens en réintégrant l'OTAN, «Le Monde» 17 II 2009.

22. Szeptycki A., Francja czy Europa? Dziedzictwo generała de Gaulle'a w polityce zagranicznej V Republiki, Warszawa 2005.

23. Terlikowski M., Europejska Polityka Bezpieczeństwa $i$ Obrony $w$ programie prezydencji francuskiej, «Biuletyn PISM» 2008, nr 33(501).

24. Wspólne oświadczenie ministrów spraw zagranicznych Francji, Niemiec i Polski w sprawie przyszłości Europy, [w:] Stosunki Międzynarodowe 1989-2000 Dokumenty i Materiały, Z. Leszczyński, A. Koseski, (red.), Pułtusk 2001.

Стаття надійшла до редколегії 10.06.2018 Прийнята до друку 01.09.2018 
ФРАНЦУЗЬКА ПОЛІТИКА БЕЗПЕКИ ПІСЛЯ 1989 РОКУ

\section{Кароліна Ужаловіч}

Вроилавський університет

вул. Кочарова, 3, м. Врочлав, Польща, 51-149, тел. +4177987 78 99,

e-mail:wojkarolina@interia.pl

Представлено специфіку французької політики безпеки, а також співпрацю Франції 3 країнами в межах Європейського Союзу та НАТО. Стаття демонструє демократичний характер французької політики безпеки, на який впливає з одного боку історичні та політичні традицій, а 3 іншого геополітичне положення. У статті наголошується про дилему перед країною: організовувати політику безпеки самостійно чи за допомогою співпраці 3 іншими країнами Європейського Союзу. У Франції, незважаючи на значні зміни після 1989, прослідковується міцна позиція Парижа в усій Європі та за іiі межами. Франція хоче займати лідируючу позицію в європейських організаціях, таких як Європейський союз, Рада Європи, вона бере активну участь у зустрічах Ради Безпеки ООН, просуваючи важливі стратегії у Європі. Париж не підтримує втручання США у внутрішні справи європейських інституцій, вважаючи це не доцільним. За президентства Жака Ширака були помітні прагнення до зміцнення співпраці з Союзом, а також повернення до інтегрованих військових структур, які були впровадженні тільки у 2009 році. Франція вважає роботу ООН надзвичайно важливою. Як представник Європи в Раді Безпеки разом 3 Великою Британією, вона має право голосу. Протягом останніх років, Париж голосував за надання більших повноважень окремим європейським країнам у лідируючих інституціях, а також запрошував нових членів до Ради Європи. В той самий час Франція не забуває про свій культурний спадок і докладає великих зусиль для його збереження.

Ключові слова: безпека; НАТО; Франція; Свропейський Союз; Рада Європи. 